\title{
Organic micropollutants (PAHs, PCBs, pesticides) in seaweeds of the lagoon of Venice
}

\section{Micro polluants organiques (HAP, PCB, pesticides) dans les macro-algues de la lagune de Venise}

\author{
Bruno Pavoni *, Michele Caliceti, Laura Sperni, Adriano Sfriso \\ Department of Environmental Sciences, Università Ca’ Foscari di Venezia, Calle Larga Santa Marta 2137, 30123 Venice, Italy
}

Received 21 November 2002; received in revised form 5 May 2003; accepted 12 May 2003

\begin{abstract}
Samples of seven genera of seaweeds (Ulva, Gracilaria, Porphyra, Grateloupia, Undaria, Fucus and Cystoseira), which can be used as environmental biomonitors and in several applications like human alimentation, animal feeding and cosmetics, were collected in four sampling sites in the Lagoon of Venice in spring and autumn 1999 with the aim of determining the contamination due to organic micropollutants (polychlorinated biphenyls, PCBs; chlorinated pesticides; polycyclic aromatic hydrocarbons, PAHs). On an average, most of the considered species were contaminated especially by PAHs (up to $56 \mathrm{ng} \mathrm{g}^{-1}$ dry wt. (dw)) whereas concentrations of PCBs and pesticides in macroalgal tissues were significantly correlated and did not exceed $5 \mathrm{ng} \mathrm{g}^{-1} \mathrm{dw}$. Among the studied genera the most contaminated by PAHs were Ulva, Undaria and Cystoseira. The highest concentrations of PCBs and pesticides were found in Cystoseira, Fucus and Gracilaria. The least contaminated genus was Porphyra. Although macroalgal specimens were sampled in differently contaminated areas placed from the mainland to the Lido Lagoon mouth, no quantitatively meaningful differences of concentrations were found among the sampling stations.
\end{abstract}

(C) 2003 Éditions scientifiques et médicales Elsevier SAS and Ifremer/CNRS/IRD. All rights reserved.

\section{Résumé}

Des échantillons de sept genres de macro-algues (Ulva, Gracilaria, Porphyra, Grateloupia, Undaria, Fucus et Cystoseira) qui peuvent être utilisées comme bio-indicateurs et dans plusieurs autres applications, comme l'alimentation humaine, animale et en cosmétique, ont été recueillis dans quatre stations d'échantillonnage dans la lagune de Venise au printemps et à l'automne 1999 pour déterminer leur contamination en micropolluants organiques (biphényls polychlorés, PCB, pesticides chlorés et hydrocarbures polycycliques aromatiques, HAP). La plupart des espèces considérées sont contaminées essentiellement par des HAP (jusqu'à $56 \mathrm{ng} \mathrm{g}^{-1}$ poids sec), tandis que les concentrations de PCB et de pesticides dans les tissus, étant bien corrélées, ne sont pas plus hautes que $5 \mathrm{ng} \mathrm{g}^{-1}$, p.s. Parmi les genres étudiés, les plus contaminés par HAP sont Ulva, Undaria et Cystoseira. Les concentrations les plus hautes de PCB et de pesticides ont été trouvés dans Cystoseira, Fucus, Gracilaria, tandis que le genre le moins contaminé est Porphyra. Bien que les échantillons de macro-algues aient été recueillis dans différents endroits de la lagune situés entre la terre ferme et l'ouverture du Lido, aucune différence significative n'a été trouvée entre les concentrations déterminées pour chaque station.

C 2003 Éditions scientifiques et médicales Elsevier SAS and Ifremer/CNRS/IRD. All rights reserved.

Keywords: Seaweeds; Venice Lagoon; PAHs; PCBs; Pesticides

Mots clés : Macro-algues ; Lagune de Venise ; HAP ; PCB ; Pesticides

* Corresponding author. Tel.: +39-041-234-8522; fax: +39-041-23-4582.

E-mail address: brown@unive.it (B. Pavoni). 


\section{Introduction}

The Lagoon of Venice is an ecosystem, located in Italy, on the north-western coast of the Adriatic sea. Its characteristics are the result of interactions between natural factors and human activities. It is subdivided into three natural areas, the southern, central and northern basins, which are separated by the Malamocco-Marghera Canal at the south and by the Burano-Torcello tidal lands at the north. The communication between the Lagoon and the sea is guaranteed by three inlets-Lido, Malamocco, Chioggia - which allow the exchange of $\sim 60 \%$ of the total water volume of the Lagoon each $12 \mathrm{~h}$. The Lagoon total surface is about $549 \mathrm{~km}^{2}$, the mean depth is $1 \mathrm{~m}$ (Gatto and Carbognin, 1981).

Lagoon water quality is influenced by inputs deriving from agriculture drainage, industrial (Porto Marghera district), and urban activities (traffic, domestic) from the cities of Mestre and Venice (Pavoni et al., 1992; Sfriso et al., 1992).

Alterations in the Lagoon hydrodynamics and increased nutrient inputs led, starting from the 1960s, to marked changes in the primary producers of the Lagoon. These were an abnormal growth of Ulva rigida (C. Ag.), whose biomass degradation caused frequent anoxic crises, a reduction of the areal distribution of the seagrasses usually found in oligotrophic environments (i.e. Cymodocea nodosa (Ucria) Asher., Zostera marina L. and Zostera noltii Hornem.) and the disappearance of many seaweeds unable to tolerate dystrophic conditions (Sfriso, 1987).

Starting from the 1990s, a strong reduction of Ulva was observed, which enabled a partial re-population of the marine phanerogams. This process, however, has been significantly limited by the harvesting of Tapes philippinarum Adams and Reeve (a bivalve introduced in the Lagoon for economic purposes), carried out by means of boats equipped with hydraulic and mechanical dredges, which resuspend the sediments (Sfriso and Ghetti, 1998; Sfriso, 2000).

At the same time not-indigenous hard bottom macroalgal species spread all over the Lagoon; examples are Sargassum muticum (Yendo) Fensholt, Undaria pinnatifida (Harvey) Suringar, and Grateloupia doryphora (Montagne) Howe.

The relevance of seaweeds in biogeochemical nutrient cycles of the Lagoon is well known; it was established that seaweeds act as a temporary reservoir of nutrients (nitrogen and phosphorus), which are then released mostly into the surface sediment and in the overlying waters (Sfriso et al., 1992; Pavoni et al., 1990).

Seaweeds, Ulva and Gracilaria in particular, are also reported to accumulate both heavy metals (Prosi, 1983; Karez et al., 1994; Haritonidis and Malea, 1995, 1999; Malea and Haritonidis, 1999a, b) and hydrocarbons such as polychlorinated biphenyls (PCBs), and pesticides (Levine, 1984 and references therein; Moy and Walday, 1996) and, as part of the ecosystem, they are exposed to the ubiquitous presence of organic micropollutants (Erickson, 1997; Neff, 1979) and can work as suitable biomonitors.
In this paper we report results on the ability of some seaweeds to accumulate polycyclic aromatic hydrocarbons (PAHs), PCBs and chlorinated pesticides, namely dichlorodiphenylthrichloroethane (DDT) and its metabolites dichlorodiphenyldichloroethane and dichlorodiphenyldichloroethylene (DDD, DDE), $\alpha-, \gamma$-hexachlorocyclohexane $(\mathrm{HCH})$, hexachlorobenzene $(\mathrm{HCB})$.

These classes of contaminants were selected for their environmental persistence (Kennish, 1994), high octanolwater partition coefficients and bioconcentration factors (Van Loon and Duffy, 2000) and well-documented toxicities toward organisms (Amdur et al., 1991; COM, 2001)

According to the Italian legislation, chlorinated pesticides such as cyclodienes (endrin, dieldrin, aldrin, etc.) were banned in 1973, DDT was discontinued in 1978, the use of $\mathrm{HCH}$ and HCB was strongly limited in 1974. PCBs use was prohibited in 1988, but electrical equipment containing PCBs is still stocked in factories and the complete removal from the territory and destruction has to be completed before 2010. PAH contamination of the Lagoon environment has not stopped, being depending on oil spills, on combustions from industrial, household, maritime and terrestrial traffic sources; it might have even augmented recently due to the traffic increase in the whole area bordering the Lagoon.

In any case, it must be considered that in the sediments of the canals of the industrial district the concentrations of the organic pollutants, especially PCBs and PAHs attain levels as high as those found in a sub-surface sediment sampled in December 2001: $\mathrm{PAH}_{\text {tot }}, 31 \pm 7 \mu \mathrm{g} \mathrm{g} \mathrm{g}^{-1} ; \mathrm{PCB}_{\text {tot }}$, $170 \pm 20 \mathrm{ng} \mathrm{g}^{-1}$; HCB, $12 \mathrm{ng} \mathrm{g}^{-1}$. Other chlorinated pesticides were $<1 \mathrm{ng} \mathrm{g}^{-1}$. Because of the sediment re-suspension due to tidal water movements, dredging operations and boat traffic, these contaminated sediments are dispersed throughout the Lagoon and constitute a continuous source of contamination. The goal of this study was of assessing a possible use of macroalgae as an analytical matrix for monitoring a mid-term Lagoon contamination-as compared to sediments (long-term) and water (instant) — and of measuring the toxicity present in algae due to organic pollutants. The studied seaweeds were $U$. rigida, Gracilaria gracilis (Stackhouse) Steentoff, Irvine and Farnham, Porphyra leucosticta Thuret, G. doryphora, U. pinnatifida, Fucus virsoides (Don.) Ag., Cystoseira barbata (Good. and Woodw.) Ag. The choice was based on their ecological relevance (the extended blooms of Ulva represented a severe problem in the 1980s, being the main cause of anoxia in the Lagoon), their dissemination and abundance. In fact, the selected species are ubiquitous in the Lagoon and represent $70-80 \%$ of the whole macroalgal biomass. In particular Ulva and Gracilaria account for approximately $94 \%$ of the standing crop of the species considered in this paper (ca. $9600 \mathrm{t}$ fresh weight [f.w.] in the central lagoon) and $98 \%$ of the gross primary production (ca. $65000 \mathrm{t} \mathrm{f.w.).}$ They are almost unaffected by the presence of pollutants and by other disturbance factors, such as particulate matter fluxes, are easy to sample and available all year round. In addition, Ulva and Gracilaria, which are very common in 
shallow European coastal areas (Morand and Briand, 1996; Schramm and Nienhuis, 1996) and form dense biomass beds in shallow and sheltered soft bottoms, provide a feeding source, a spawning area and nursery for young fish and other organisms and a shelter against predators. For instance a recent work of Balducci et al. (2001) showed that in some lagoon areas about 5.5-9.5\% of the Ulva standing crop is daily fed by invertebrates herbivores, especially Gammarus aequicauda Martinov. That amount almost corresponded to the biomass production of this species in the study areas.

The same environmental role is played in the hard bottoms by Cystoseira and Undaria, which however, cover only a very limited surface of the Lagoon $(<5 \%)$.

Fucus, Undaria, Gracilaria, Grateloupia and Porphyra can be considered also for their potential use in several applications like human alimentation and animal feeding (direct or as source of agar-agar, carrageenin and alginic acid: Keiji and Kanji, 1989;Bressan and De Luca, 1987; Penso, 1987). Since 1940s Gracilaria spp. was in fact intensively collected in the Lagoon for agar production reaching the highest harvesting rate in 1985 with 1700 t on dry weight basis (Orlandini and Favaretto, 1987).

\section{Materials and methods}

\subsection{Sampling sites}

Seaweed samples were collected at four sampling sites located in the central lagoon, referred to as Ponte della Libertà (St. 1), Tronchetto (St. 2), Celestia (St. 3), Lido inlet (St. 4) (Fig. 1), characterized by different human impacts and different hydrodynamic and natural conditions.

St. 1, Ponte della Libertà, is the closest to the industrial area of Porto Marghera where a number of chemical industries are still in operation. The site is near the bridge connect- ing Venice to the city of Mestre and is characterized by an intense vehicle traffic. Water renewal is rather low.

St. 2, Tronchetto, is located near the parking lot of Tronchetto; the main human influence is due to maritime traffic; the water exchange is guaranteed by the adjacent Vittorio Emanuele canal.

St. 3, Celestia, represents an area characterized by strong domestic inputs and maritime traffic; further human influence is due to glass-factories in the island of Murano located very near.

The morphology of the area allows a reduced water exchange.

St. 4, Lido inlet, is assumed to be the least contaminated site, because of the limited human influences and the strong water exchange with the sea.

\subsection{Seaweed sampling}

At each station, seaweeds were collected in spring (April) and autumn (October) during the two highest growth periods usually monitored in the Venice lagoon (Sfriso and Pavoni, 1994). At no station it was possible to sample all the considered species. At the Celestia, six species were found, whereas at Lido inlet and Tronchetto only five species were monitored and at Ponte della Libertà only Ulva and Gracilaria were present. These latter were found at all the four stations, possibly the species able to tolerate high levels of eutrophication and contamination. Fucus was monitored only at the Lido inlet station because this species does not tolerate periods of hypoxic conditions similar to those, which are likely to occur in the other sampling areas. Whereas Ulva, Gracilaria, Grateloupia, Cystoseira and Fucus were found in April and October, Undaria and Porphyra were sampled only in April. Each species was sampled by collecting the whole thallus. Only thalli attached on to the substrate (banks, stones, dams) of the sampling areas were collected. Since Cystoseira and
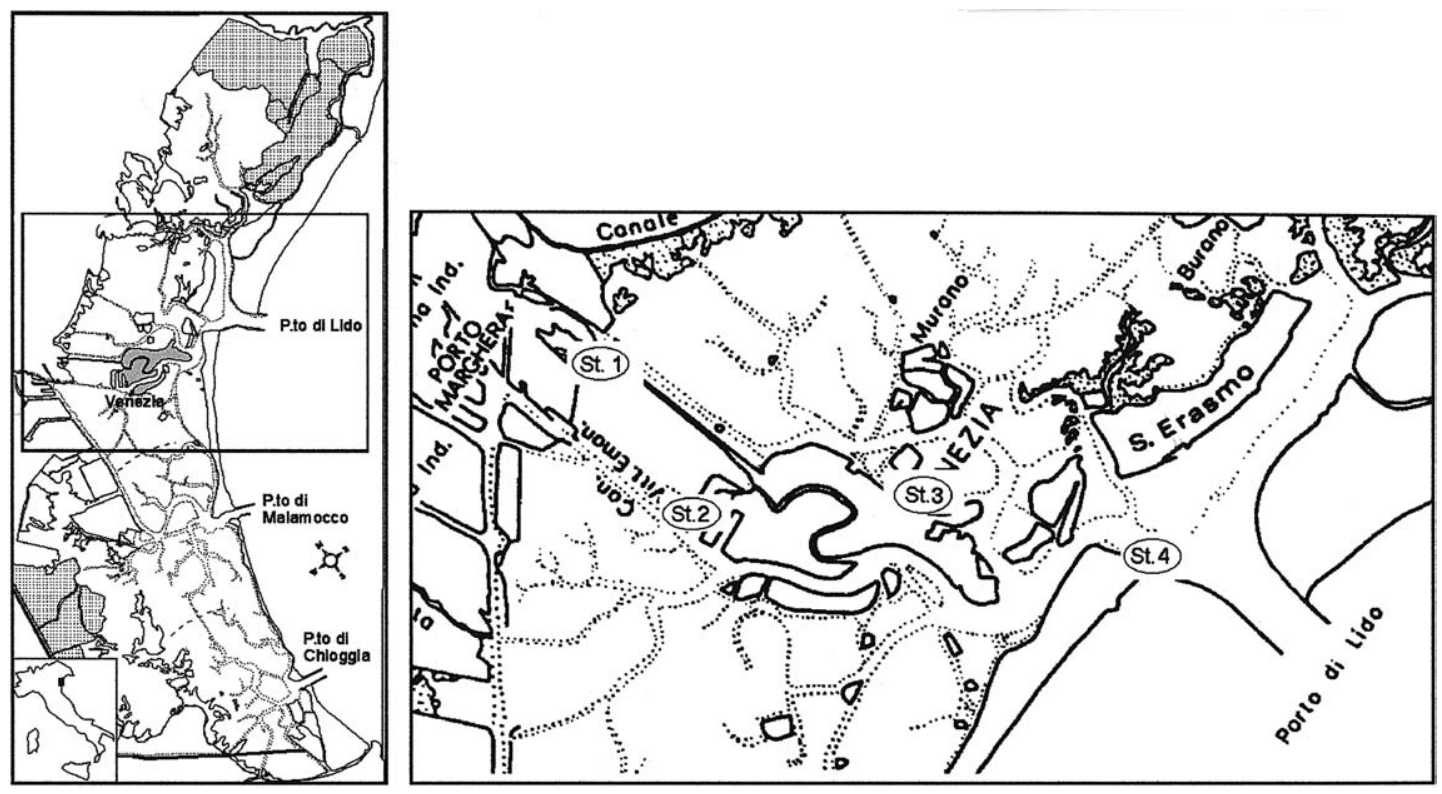

Fig. 1. Location of the sampling stations in the central basin of the Lagoon of Venice. 
Gracilaria grow exclusively in the subtidal zone and Ulva, Undaria and Grateloupia grow both in the lower intertidal and subtidal zones, samplings were performed during low tide to render their collection easier. In contrast, Porphyra and Fucus grow only in the upper part of the intertidal zone and during low tide are exposed to air. These species were sampled during high tide.

Thalli of species featuring a small or medium size (Ulva, Gracilaria, Fucus, Grateloupia, Porphyra) or the big ones (Cystoseira, Undaria) were collected in a number sufficient to obtain representative samples (a combination of three subsamples, from 0.5 to $2 \mathrm{~kg}$ f.w.) taking into account the specimens' age and the peculiarities of the different locations in the sampling areas. Samples were carefully rinsed with lagoon water to remove particulate matter and epiphytes and then stored at $-20{ }^{\circ} \mathrm{C}$. After freeze-drying they were crashed and homogenized in a mortar. The whole tissue was analyzed. The residual water content was determined to correct the final values.

\section{Materials}

The used solvents were RS and HPLC grade. Silica gel RS (0.05-0.2 mm, Carlo Erba), neutral aluminum oxide RS, Florisil RS (60-100 mesh, Carlo Erba), anhydrous sodium sulfate RPE (Carlo Erba) were activated at $250{ }^{\circ} \mathrm{C}$ for $10 \mathrm{~h}$. Six grams of silica gel and $8 \mathrm{~g}$ aluminum oxide-deactivated (1.5\%) with Milli-Q water-were soaked with $n$-hexane/ dichloromethane (4:1 v:v) in a flask, degassed and equilibrated in an ultrasonic bath for about $1 \mathrm{~h}$. Copper powder (100 mesh, Carlo Erba) was activated in a little glass column with $1 \mathrm{~N} \mathrm{HCl}$ and then rinsed with methanol and the $n$-hexane/dichloromethane mixture (4:1 v:v).

The following standards were used. For PCBs a mixture of 21 congeners (Lab Service, Bologna, Italy) was employed. The list in order of elution is the following: CB 18; CB 54, CB 28; CB 52; CB 155; CB 101; CB 77, CB123; CB 118; CB 153; CB105; CB 138; CB126; CB 185; CB 156; CB 157; CB 198; CB 169; CB 170; CB 194; CB 209.

For the pesticides, the standard solution contained nine compounds: $\alpha-\mathrm{HCH}, \mathrm{HCB}, \gamma-\mathrm{HCH}, o, p^{\prime}-\mathrm{DDE}, p, p^{\prime}$-DDE, $o, p^{\prime}$-DDD, $p, p^{\prime}$-DDD, $o, p^{\prime}$-DDT, $p, p^{\prime}$-DDT.

For the PAHs the standard solution contained $16 \mathrm{com}-$ pounds including three internal standards; the list in order of elution is the following: naphtalene ${ }_{\mathrm{d} 8}$ as internal standard (i.s.), acenaphthylene, acenaphthene, fluorene; phenanthrene $_{\mathrm{d} 10}$ (i.s.), phenanthrene, anthracene, fluoranthene, pyrene, benzo(a)anthracene, perylene $\mathrm{d}_{12}$ (i.s.), chrysene, benzo(k)fluoranthene, benzo(a)pyrene, dibenzo(a,h)anthracene, benzo(g,h,i)perylene.

\subsection{Extraction}

About $5 \mathrm{~g}$ of freeze-dried sample were weighed in a flask. The extraction was made with three $30 \mathrm{ml}$ aliquots of a mixture of $n$-hexane/dichloromethane (4:1 v:v) for $2 \mathrm{~h}$ of sonication; the three extracts were joined together and evaporated in a rotary evaporator to $1-1.5 \mathrm{ml}$ at a low temperature and weak vacuum. Two replicates of each sample were prepared.

\subsection{Purification and separation}

Glass chromatographic columns of $1 \mathrm{~cm}$ internal diameter and $45 \mathrm{~cm}$ length with a Teflon stopcock and a $80 \mathrm{ml}$ reservoir were packed as described in Raccanelli et al. (1994).

After introducing the sample, three fractions were obtained: by eluting $30 \mathrm{ml} n$-hexane (first fraction containing alkanes), then $70 \mathrm{ml} n$-hexane (second fraction with PCBs); then $75 \mathrm{ml} n$-hexane/dichloromethane (3:2 v:v) (third fraction with PAHs). Pesticides were mostly found in the third fraction, but some, or fractions of them were also occasionally identified in the second.

The fractions were concentrated with a rotary evaporator to $1 \mathrm{ml}$ and then pipetted into glass vials. Small washing volumes of $n$-hexane were used for complete transfer of analytes.

After evaporation to dryness at room temperature, the extracts were re-dissolved in $500 \mu \mathrm{l}$ of isooctane and stored at $-20{ }^{\circ} \mathrm{C}$. Before the instrumental analysis, vials were let return to room temperature.

\subsection{Instrumental analysis}

PCBs and pesticides were detected with a gas chromatograph Hewlett-Packard 5890 Series II equipped with a ${ }^{63} \mathrm{Ni}$ electron capture detector-ECD, a HP Ultra 2 column (crosslinked 5\% phenylmethylsiloxane, $0.33 \mu \mathrm{m}$ layer) $-0.2 \mathrm{~mm}$ i.d. and $50 \mathrm{~m}$ length — and a splitless injector. The carrier gas was $\mathrm{He}$, at a flow rate of $0.8 \mathrm{ml} \mathrm{min}^{-1}$. The injector was heated at $250{ }^{\circ} \mathrm{C}$, whereas the detector temperature was $300{ }^{\circ} \mathrm{C}$. The temperature of the column was $110^{\circ} \mathrm{C}$, held for $1 \mathrm{~min}$, raised to $141^{\circ} \mathrm{C}$ at $9{ }^{\circ} \mathrm{C} \min ^{-1}$, to $271^{\circ} \mathrm{C}$ at $5^{\circ} \mathrm{C} \mathrm{min}{ }^{-1}$, to $280{ }^{\circ} \mathrm{C}$ at $2{ }^{\circ} \mathrm{C} \mathrm{min}^{-1}$, held for $15 \mathrm{~min}$. The total runtime was $49.9 \mathrm{~min}$. One or $2 \mu \mathrm{l}$ were manually injected. The internal standard method was routinely used to assure reproducibility of the GC analysis.

PAHs were detected with a Hewlett-Packard gas chromatograph-mass spectrometer (GC-MS: 5890 Series II5970 MSD Series) equipped with a capillary HP Ultra 2 column (crosslinked 5\% phenylmethylsiloxane, $0.33 \mu \mathrm{m}$ layer)— $0.2 \mathrm{~mm}$ i.d. and $50 \mathrm{~m}$ length—and a splitless injector. The gas carrier was He at a flow rate of $1 \mathrm{ml} \mathrm{min}^{-1}$. The injector was heated at a temperature of $300{ }^{\circ} \mathrm{C}$; the column temperature was $60^{\circ} \mathrm{C}$ for $1 \mathrm{~min}$, then it was raised to $140{ }^{\circ} \mathrm{C}$ at $15.0{ }^{\circ} \mathrm{C} \mathrm{min}{ }^{-1}$, to $250{ }^{\circ} \mathrm{C}$ at $5.5{ }^{\circ} \mathrm{C} \mathrm{min}{ }^{-1}$, to $290{ }^{\circ} \mathrm{C}$ at $5.0{ }^{\circ} \mathrm{C} \mathrm{min}^{-1}$ and kept for $25 \mathrm{~min}$. The total runtime was $59.3 \mathrm{~min}$. The spectrometer was used in selected ion monitoring mode (SIM).

The internal standards used were congeners of the classes of pollutants not present in the sample, i.e. CB30 and deuterated PAH. 


\section{Results and discussion}

\subsection{Concentration levels of pollutants in seaweed tissues}

In previous publications Pavoni et al. (1990), Maroli et al. (1993) and Picer (2000) reported the concentrations of PCBs and chlorinated pesticides in specimens of algae from the Venice lagoon. Unfortunately a direct comparison with those data is difficult as in those studies a different set of algae species and different sampling stations were chosen. In addition a quantification standard for PCBs based on Aroclor 1254 was used. An important observation was reported in the paper of Maroli et al. (1993). The concentrations of halocarbons in the same species of alga may significantly depend on the age and/or condition of the fronds: old, decomposing fronds can contain significantly higher amounts of pollutants. In the present work only fresh specimens in good living conditions were collected.

Using the sum of determined congeners, for each micropollutant category, the average, minimum and maximum concentration values were calculated using all the obtained results (Table 1). The same parameters were also determined for each genus, including the results obtained for the two sampling periods and the four sampling sites. PCBs and pesticides, on the basis of the obtained data, showed an analogous behavior, never exceeding the concentration of $5 \mathrm{ng} \mathrm{g}^{-1} \mathrm{dw}$ in any of the investigated species. Since the concentrations of these two categories of micropollutants were significantly correlated $(r=0.86, P<0.05, N=30)$ they were discussed together as chlorinated organic hydrocarbons (COHs) (Fig. 2). Fig. 3 represents the distribution of the mean values, determined for each genus as already explained, in the $\mathrm{COH}-$ $\mathrm{PAH}$ plane; lines represent the overall mean values.

Among the four genera exceeding the general mean values for COHs, $C$. barbata had the highest contamination, followed by $F$. virsoides, $G$. gracilis and $U$. pinnatifida. The lowest mean values were observed for the genera $U$. rigida C. Ag. and P. leucosticta. Concerning the sum of PAHs, an average concentration of $7 \mathrm{ng} \mathrm{g}^{-1} \mathrm{dw}$ was found. In calculating this mean value, an exceptionally high concentration of $56.4 \mathrm{ng} \mathrm{g}^{-1}$ found in only one sample was not included.

The genera with a mean value exceeding the overall mean were Undaria, Ulva and Cystoseira. The lowest mean values were detected for Fucus and Gracilaria.

The level and characteristics of organic contamination can depend on several factors:

- Factors linked to seaweed morphology (available surface, rugosity); life cycle (perennial, seasonal), i.e. time of exposure; chemical composition (fat content); position in the water column related to the chemical behavior of the contaminants (e.g. PAHs from boat engine exhausts tend to concentrate in the surface water film (Cincinelli et al., 2001; Yunker et al., 2001); specific metabolic transformations (Moy and Walday, 1996).

- Factors linked to the chemical characteristics of the contaminant: solubility, photochemical reactivity, volatility, bioconcentration factor or accumulation tendency $\left(K_{\text {ow }}\right)$ (Erickson, 1997; Neff, 1979).

- Environmental factors: pollutant sources, amount of suspended particulate matter (SPM) (Neff, 1979; Strandberg et al., 1998).

Table 1

Maximum, mean with the standard deviation (of all not equal to zero values) and minimum detected concentration values of the studied compounds

\begin{tabular}{lllll}
\hline Concentration in $\mathrm{ng}^{1} \mathrm{dw}$ & & PCBs & Pesticides & PAHs \\
\hline Overall & Max & 4.2 & 4.9 & 56.4 \\
& Mean & 1.5 & 1.4 & 7.0 \\
\hline Ulva & Min & 0.1 & 0.2 & 56.4 \\
& Max & 1.8 & 1.7 & $3.5 \pm 3.0$ \\
\hline Gean & $0.7 \pm 0.6$ & $0.9 \pm 0.2$ & 1.0 \\
& Min & 0.1 & 0.2 & 6.5 \\
& Max & 3.8 & 2.8 & $4.2 \pm 1.7$ \\
\hline Porphyra & Mean & $2.0 \pm 1.2$ & $1.5 \pm 0.2$ & 1.3 \\
& Min & 0.6 & 0.4 & 6.2 \\
& Max & 1.1 & 0.8 & $5.1 \pm 1.0$ \\
\hline Grateloupia & Mean & $0.8 \pm 0.3$ & $0.7 \pm 0.1$ & 4.4 \\
\hline Min & Max & 0.5 & 0.6 & 7.4 \\
& Mean & 1.4 & 0.9 & 3.3 \\
\hline Mucus & Min & $1.1 \pm 0.3$ & $0.8 \pm 0.1$ & 30.9 \\
& Max & 0.8 & 0.7 & $17.3 \pm 19.3$ \\
& Mean & 1.7 & 1.8 & 3.6 \\
\hline Cystoseira & Min & $1.64 \pm 0.03$ & $1.74 \pm 0.02$ & 5.0 \\
& Mean & 1.6 & 1.7 & $3.5 \pm 2.1$ \\
\hline
\end{tabular}




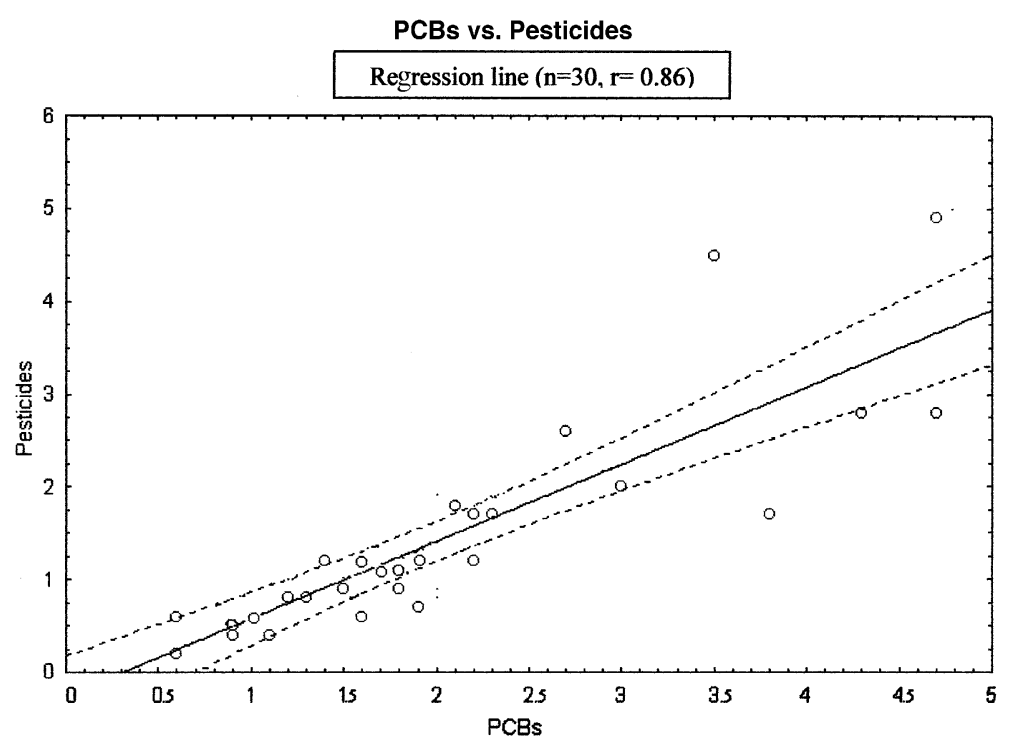

Fig. 2. Regression line obtained using all the concentrations (ng/g, dw) of $\mathrm{COHs}$ detected in the seaweed species during the first and second sampling period at the four stations.

Among the above-mentioned factors, the most meaningful in determining the contamination levels for $\mathrm{COHs}$ seem to be the life cycle. Cystoseira, Fucus, Gracilaria, which are perennial seaweeds showed higher levels of contamination than Porphyra (short seasonal life cycle) or Ulva and Grateloupia, which exhibit thalli of 1-3 months. Further, the same low values of Ulva and the higher ones of Undaria (thalli older than 6 months) suggest, beside the factor time, the importance of other factors such as the chemical composition (Ulva was reported having only $0.6 \mathrm{~g}$ per $100 \mathrm{~g} \mathrm{dw}$ of fat content, whereas Undaria had 3.2 g per $100 \mathrm{~g} \mathrm{dw}$ (Keiji and Kanji, 1989)). Another factor that seems to play a relevant role is the morphology of the thalli, which enables seaweeds to trap suspended particles and the contaminants adsorbed on them. Most of PCBs, in saline or brackish water, are associated with SPM, as reported by other studies (Raccanelli et al., 1989; Schulz-Bull et al., 1998). SPM is easily trapped by the mucilaginous surface of some species such as Undaria,
Grateloupia and Porphyra, by the roughness of many Phaeophyceae such as Cystoseira and Fucus, which have a surface covered by hairs and paraphyses or by a micro-epiphytic layer of diatoms. For PAHs the most important factors seem to be the bathymetric distribution of seaweeds and their morphology. For example, Cystoseira and Undaria are located in the subtidal zone and in the lower intertidal zone, respectively. As a consequence, Cystoseira is likely less in contact with the surface water layer, characterized by high concentration of combustion-derived PAHs, whereas the large and mucilaginous thalli of Undaria, partly floating in the PAHs enriched film during low tide are for this reason characterized by higher contamination.

The relevance of the large leaf-shaped morphology, in addition to the different depth, emerges by comparing Gracilaria (subtidal zone and cord-shaped) and Porphyra (upper intertidal zone and leaf-shaped thallus) at the three stations where they were sampled (Fig. 4).

\section{Scatterplot}

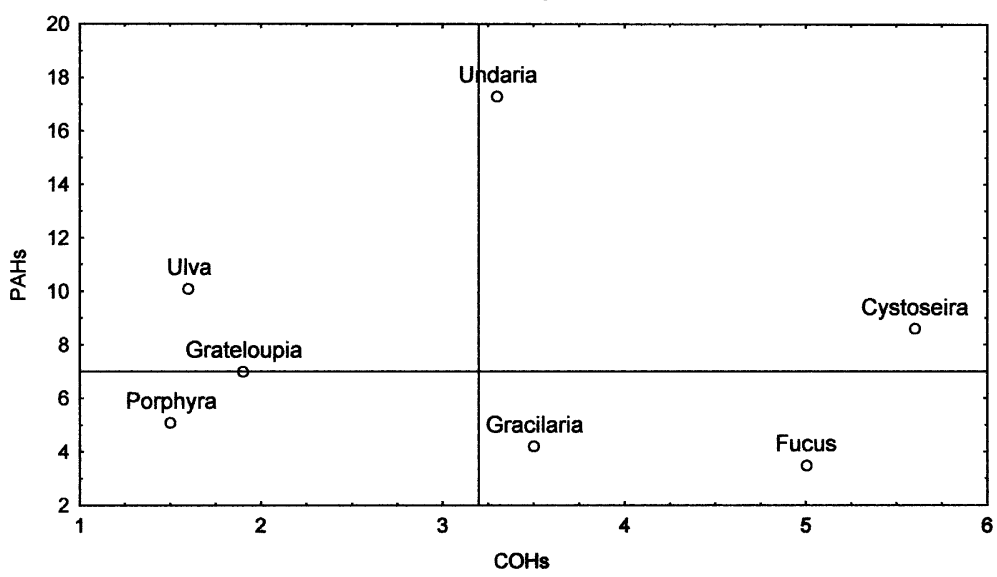

Fig. 3. Distribution of the mean pollutant concentrations ( $\mathrm{ng} \mathrm{g}^{-1}$ d.w) in the sampled seaweeds in COH-PAH plane; lines indicate the overall mean values. 

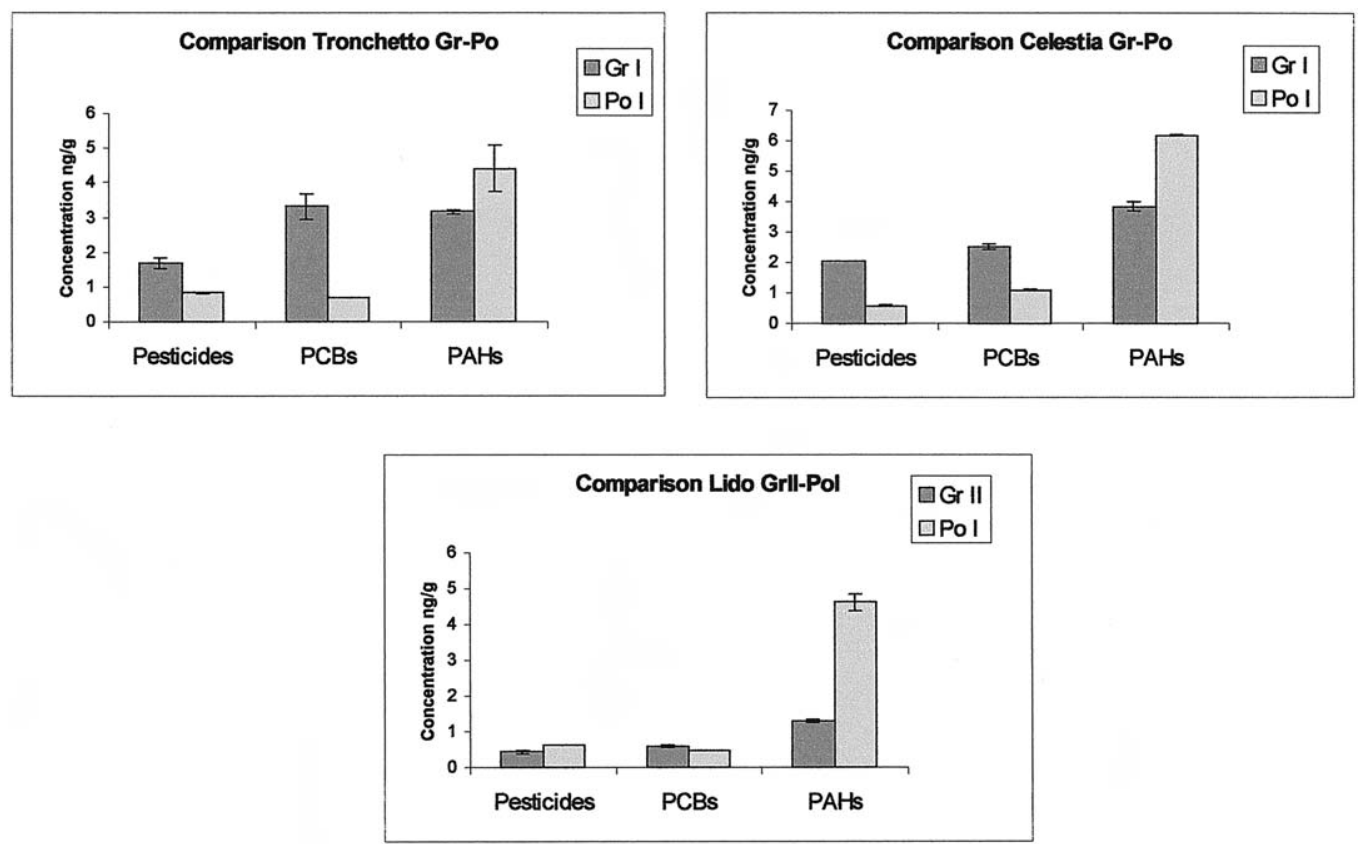

Fig. 4. Comparison of the pollutant concentrations detected for Gracilaria (Gr) and Porphyra (Po) in the stations where they were collected during first (I) or second (II) sampling period.

The contamination due to PAHs was always higher for Porphyra, even if Gracilaria is characterized by a longer life cycle.

After having considered the general behavior of the categories of micropollutants, next, the different organic contaminants will be considered more closely, by investigating the occurrence of single congeners.

\subsection{Polychlorinated biphenyls (PCBs)}

In Table 2 are presented the percentages of samples in which the particular congeners were found.

Among the 21 searched PCBs congeners the most frequently present (frequency $>60 \%$ ) were CB $28, \mathrm{CB} 52$, CB 101, CB 153, CB 138, which are also reported in several

Table 2

Percentage of samples where the particular congeners were detected. Congeners are listed according to increasing number of chlorines (PCBs) or aromatic rings (PAHs)

\begin{tabular}{|c|c|c|c|c|c|}
\hline PCBs & Frequency $(\%)$ & Pesticides & Frequency $(\%)$ & PAHs & Frequency $(\%)$ \\
\hline CB 18 & 17 & $\alpha-\mathrm{HCH}$ & 3 & Acenaphthylene & 43 \\
\hline CB 28 & 77 & HCB & 23 & Acenaphthene & 43 \\
\hline CB 54 & 0 & $\gamma-\mathrm{HCH}$ & 40 & Fluorene & 77 \\
\hline CB 52 & 60 & $o, p^{\prime}-\mathrm{DDE}$ & 13 & Phenanthrene & 100 \\
\hline CB 77 & 7 & $p, p^{\prime}-\mathrm{DDE}$ & 100 & Anthracene & 100 \\
\hline CB 101 & 100 & $o, p$ '-DDD & 100 & Fluoranthene & 97 \\
\hline CB 118 & 53 & $p, p '-\mathrm{DDD}$ & 97 & Pyrene & 97 \\
\hline CB 126 & 3 & $o, p^{\prime}-\mathrm{DDT}$ & 43 & Benzo(a)anthracene & 93 \\
\hline CB 123 & 63 & $p, p '-\mathrm{DDT}$ & 80 & Chrysene & 83 \\
\hline CB 105 & 3 & & & Benzo(k)fluoranthene & 13 \\
\hline CB 155 & 53 & & & Benzo(a)pyrene & 50 \\
\hline CB 153 & 100 & & & Dibenzo(a,h)anthracene & 10 \\
\hline CB 138 & 100 & & & Benzo(g,h,i)perylene & 57 \\
\hline CB 156 & 47 & & & & \\
\hline CB 169 & 0 & & & & \\
\hline CB 185 & 3 & & & & \\
\hline CB 170 & 47 & & & & \\
\hline CB 198 & 3 & & & & \\
\hline CB 194 & 10 & & & & \\
\hline CB 209 & 0 & & & & \\
\hline
\end{tabular}


studies as the most abundant in water and organisms tissues (Marchand et al., 1990; Cescon, 1992; Cubadda et al., 1998; Fernández et al., 1999).

Unfortunately a comparison between the pattern of $\mathrm{CB}$ congeners in samples of algae, water and particulate matter from the Lagoon of Venice was very difficult. In fact, in a previous paper (Maroli et al., 1993) reported only the sums of PCBs (as Aroclor) and Moret et al. (1999) published results concerning one sample of water and particulate matter, in which, a different set of congeners were determined.

The largest contribution $(>5 \%)$ to $\mathrm{PCB}$ contamination was due to CB 18, CB 28, CB 52, CB 101, CB 153, CB 138. It was evident the prevalence of less substituted congeners amongst the determined PCBs in the studied samples.

Seaweeds species in which a larger number of detected congeners was found, were Gracilaria and Ulva: 14 out of the 21 congeners searched. In these two genera also PCBs with high substitution degree were found. The genus with the lowest number of PCB congeners was Undaria. The distribution pattern of different congeners for the sampled sea- weeds was rather different. It is possible to recognize two main profiles:

- the first one (Gracilaria and Ulva) is characterized by the presence of the less substituted PCBs (CB 18, CB 28, CB 52, 101) (Fig. 5a);

- the second one (Porphyra and Undaria) showed the prevalence of CB 101, CB 153, CB 138 (Fig. 5b);

Cystoseira, Fucus, Grateloupia showed a intermediate profile.

Comparing the obtained trends with those reported in other studies regarding $\mathrm{PCB}$ congener distributions in seawater and in SPM (Schulz-Bull et al., 1998; Marchand et al., 1990) it can be observed that, whereas Ulva and Gracilaria profiles are more similar to the ones of seawater, Porphyra and Undaria are characterized by a SPM-like profile. Contamination for the last two genera is likely due to adsorbed SPM on their surface rather than passive sorption from solution (reported as the aquatic plants mechanism of uptake of PCBs) (Hope et al., 1997). What Porphyra and Undaria have in common, despite the different size and thallus structure,

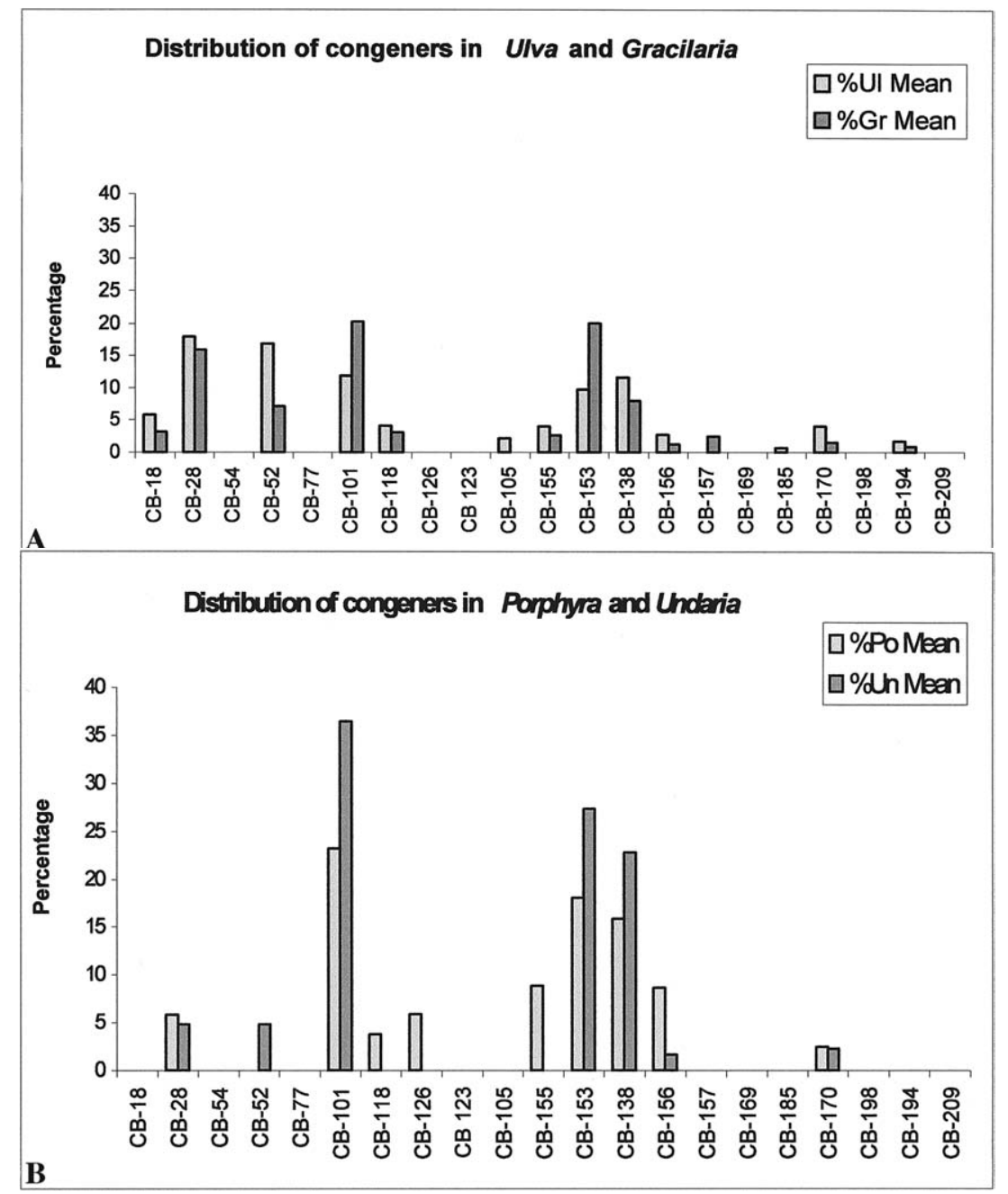

Fig. 5 (A, B). Distribution of Pcb congeners in Ulva (Ul) and Gracilaria (Gr) (Part A) and of Porphyra (Po) and Undaria (Un) (Part B) expressed as mean percentage (Congener $\mathrm{i}_{\mathrm{i}=1} / \sum_{\mathrm{n}}^{\mathrm{n}}$ Congener $_{\mathrm{i}}$ ). Congeners are listed according to increasing number of chlorine atoms. 
are a large leaf-shaped morphology and a mucilaginous surface. A combination of these factors is most likely the reason for the observed evidence.

\subsection{Pesticides}

In the majority of samples, the following DDT metabolites were found: DDD representing $51 \%$ of the total DDTrelated compounds, DDE, 34\%, whereas DDT was only $16 \%$.

Among the collected samples, few showed a different behavior; Ulva and Cystoseira from the sampling sites of Tronchetto and Celestia were characterized by high values of $p, p^{\prime}$-DDT and rather low values of its metabolites, indicating a possible recent illegal use.

Concerning the frequency of the particular compounds, Table 2 shows the percentage of samples where the contaminants were found; mostly the DDT metabolites were present. $\mathrm{HCB}$, which was never used as a pesticide in the Lagoon area, being, on the contrary, an industrial by-product, was found in few samples and its quantity was just above the detection limit; the highest values were around $0.1 \mathrm{ng} \mathrm{g}^{-1} \mathrm{dw}$.

$\gamma$-HCH (lindane) was also found in $40 \%$ of the collected samples but its values were rather low, never exceeding $0.1 \mathrm{ng} \mathrm{g}^{-1} \mathrm{dw}$.

\subsection{Polycyclic aromatic hydrocarbons (PAHs)}

PAH contamination was mainly due to tri-aromatics and tetra-aromatics: phenanthrene and anthracene were detected in all the sampled genera and represented $14 \%$ of the total PAH content; fluoranthene, found in $97 \%$ of the samples, accounted for $22 \%$; pyrene, detected in $97 \%$ of the cases represented $28 \%$ of PAH contamination (Table 2). Diaromatics (acenaphtylene, acenaphthene, fluorene) rarely reached $10 \%$ of the total PAHs contamination, but for Fucus they represented $31 \%$.

The individual compounds were investigated to detect a specific behavior of the genera and differences among the sampling stations. Samples of Gracilaria (Fig. 6a) and Ulva (Fig. 6b) represented almost $50 \%$ of the total. In Gracilaria samples, in the four stations, fluoranthene and pyrene were always the most abundant PAH, whereas other compounds were not present or just above the detection limit.

At the different sampling stations the abundances of PAH congeners in Ulva varied; several compounds were present with comparable concentrations, but phenanthrene, anthracene, fluoranthene, pyrene and benzo(a)anthracene were the most abundant. Among the stations, Lido inlet was characterized by the presence of the compounds with higher molecular weight.

Among the other investigated genera, Grateloupia and Porphyra showed the same profile as Gracilaria with differences in the relative abundances of congeners. Fluoranthene and pyrene were still the most abundant, but the presence of phenanthrene and anthracene was also important, especially for Porphyra. This fact could be due to the low bathymetric distribution of this species (Table 3 ).

By comparing Cystoseira and Fucus at the station of Lido inlet it emerges that both these species were characterized by compounds with lower molecular weight (Table 3). Summing up these evidences, it seems that different genera may accumulate different PAH congeners. In particular, whereas in the profile of PAHs in Gracilaria, which was found constantly the same in the four sampling sites, the almost exclusive presence of fluoranthene and pyrene was evident, in that of Ulva more compounds were found with comparable amounts; this could be linked to the large leaf-shaped morphology and to the lower bathymetric distribution of Ulva, which causes this species to be more in contact with the PAH enriched surface layer. Studies concerning the Venice Lagoon sediments indicated the pyrolithic source as the main source for this contamination (Wetzel, 2000).

\section{Conclusions}

Average concentrations of PAHs (mainly tri-, tetraaromatic compounds) in the considered seaweeds of the Venice lagoon were found below $10 \mathrm{ng} \mathrm{g}^{-1} \mathrm{dw}$ whereas PCB and pesticide concentrations were averagely even lower $\left(<2 \mathrm{ng} \mathrm{g}^{-1}\right)$. PAHs, due to the intense boat traffic across the Lagoon are especially concentrated in the surface water film and accumulate mostly in Ulva, Undaria and Cystoseira. The first genus has a leaf shaped thallus with a high surface/volume ratio and is frequently in contact with the PAH enriched surface film; Undaria and Cystoseira are big size seaweeds with a very complex morphology able to accumulate contaminants because of their rugosity (Cystoseira), the mucilaginous structure of the external thalli (Undaria) and long life cycles.

The highest concentrations of PCBs and pesticides were found in Cystoseira and Fucus, two Phaeophyceae species characterized by a perennial life cycle and thus by a longer exposure period to contaminants. PCBs displayed two main profiles, one characterized by the presence of the less substituted compounds (Gracilaria and Ulva) and the other by the higher substituted congeners (Porphyra and Undaria). These species exhibited a SPM-like profile due to their large leafshaped morphology and a mucilaginous surface able to retain SPM particles.

$\Sigma$ DDT content in seaweed tissues was negligible and mainly due to the prevalence of the metabolites DDD (51\%) and DDE (34\%).

By considering Ulva and Gracilaria, the only genera found in all the studied stations, it was not possible to detect a typical profile of pollutant congeners for the individual sampling areas. Moreover, no unique temporal trend was observed.

From these results the use of the considered seaweeds in cosmetics and/or animal feeding appears possible, on condition that specimens are collected in the subtidal zone in order to minimize PAH contamination. 

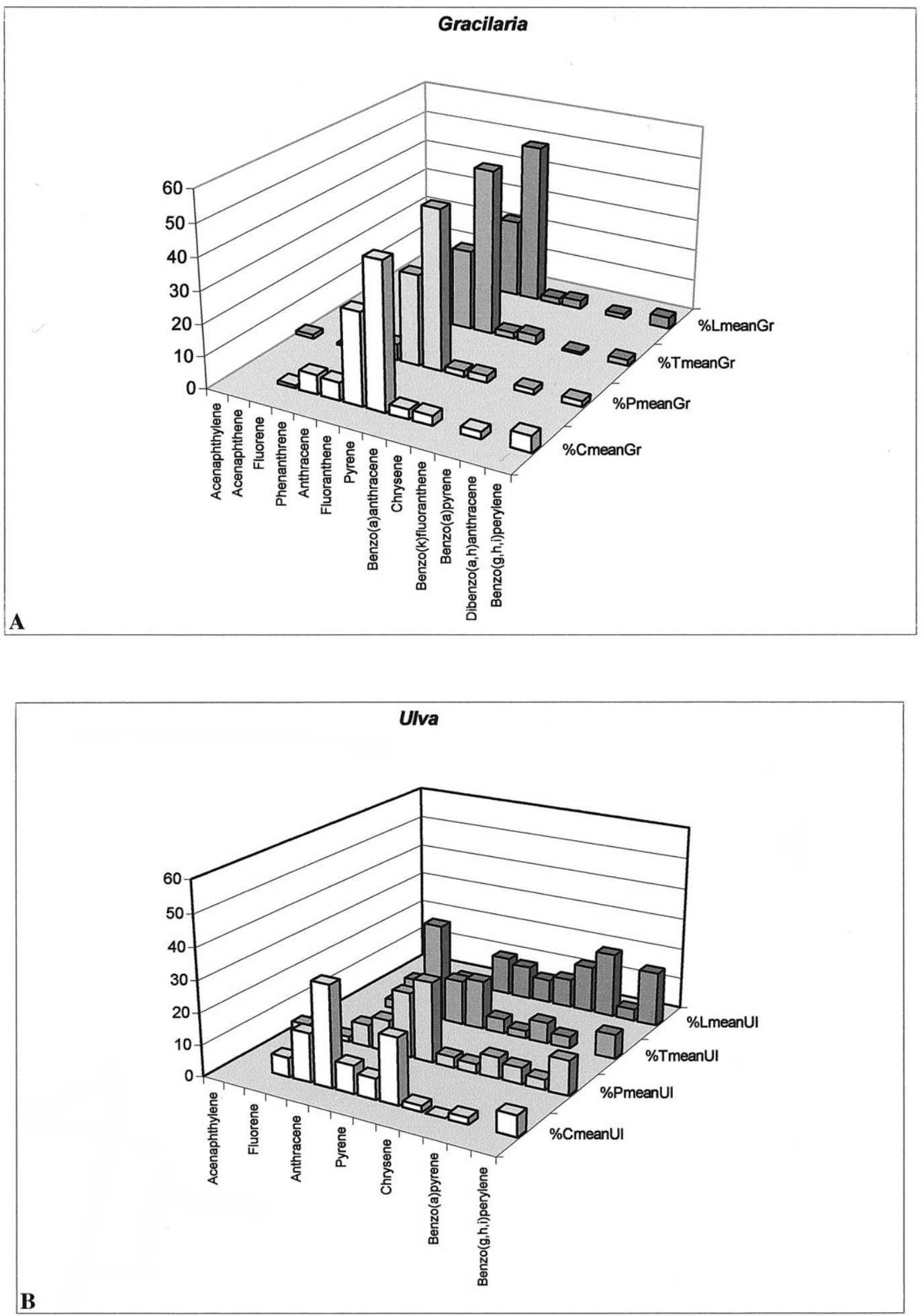

Fig. 6 (A, B). Distribution of PAH congeners expressed as mean percentage (Congener $\left.\mathrm{i}_{\mathrm{i}=1} \sum_{\mathrm{i}}^{\mathrm{n}} \mathrm{PAH}_{\mathrm{i}}\right)$ for Gracilaria $(\mathrm{Gr})(\mathrm{Part} \mathrm{A})$ and for $U l v a(\mathrm{Ul})(\mathrm{Part} \mathrm{B})$ at the four sampling sites $(\mathrm{P}=$ Ponte della Libertà, St. 1; $\mathrm{T}=$ Tronchetto; St. 2; C = Celestia, St. 3; L = Lido inlet, St. 4). 
Table 3

Percent amounts of different congeners in the sums of PAHs determined in the samples of Grateloupia, Porphyra, Cystoseira and Fucus in the sampling stations. Blank boxes: congener not found. Zero values: congener found, but very low concentration. The number of significant figures of data are set on the basis of the half variation interval between replicates

\begin{tabular}{|c|c|c|c|c|c|c|c|c|}
\hline & \multicolumn{2}{|c|}{ Grateloupia } & \multicolumn{3}{|c|}{ Porphyra } & \multicolumn{2}{|c|}{ Cystoseira } & \multirow{2}{*}{$\begin{array}{l}\quad \text { Fucus } \\
\text { St. } 4\end{array}$} \\
\hline & St. 2 & St. 3 & St. 2 & St. 3 & St. 4 & St. 3 & St. 4 & \\
\hline Acenaphthylene (\%) & 2 & 2 & & & & 3 & 12 & 20 \\
\hline Acenaphthene (\%) & 1 & 1 & & & & 2 & 2 & 2 \\
\hline Fluorene (\%) & 2 & 4 & & & 1 & 4 & 24 & 8 \\
\hline Phenanthrene (\%) & 7 & 10 & 14 & 8 & 18 & 8 & 24 & 29 \\
\hline Anthracene (\%) & 3 & 6 & 16 & 12 & 7 & 4 & 8 & 6 \\
\hline Fluoranthene (\%) & 17 & 22 & 25 & 27 & 23 & 15 & 16 & 18 \\
\hline Pyrene (\%) & 33 & 32 & 23 & 27 & 23 & 28 & 13 & 15 \\
\hline Benzo(a)anthracene (\%) & 1 & 3 & 4 & 5 & 5 & 5 & 1 & 1 \\
\hline Chrysene (\%) & 1 & 2 & 7 & 9 & 8 & 5 & 0 & 1 \\
\hline Benzo(k)fluoranthene (\%) & & & & & & 0 & 0 & 0 \\
\hline Benzo(a)pyrene (\%) & 3 & 7 & 5 & 5 & 7 & 4 & 0 & 0 \\
\hline Dibenzo(a,h)anthracene (\%) & & & & & & 0 & 0 & 0 \\
\hline Benzo(g,h,i)perylene $(\%)$ & 30 & 11 & 6 & 7 & 8 & 22 & 0 & 0 \\
\hline
\end{tabular}

Some species such as Ulva and Cystoseira which are present all year long, and especially Ulva which thrives both in low and high contaminated environments, can be employed as environmental biomonitors useful for displaying a mid-term contamination.

\section{Acknowledgements}

This work was partly supported by the Consortium for Coordination of Research Activities Concerning the Venice Lagoon System (CORILA). The authors thank Mrs. Sonia Ceoldo for technical assistance and Dr. Orietta Zucchetta for editing the English text.

\section{References}

Amdur, M.O., Doull, J., Klaassen, C.D., 1991. Casarett and Doull's Toxicology. fourth ed. McGraw-Hill, New York.

Balducci, C., Sfriso, A., Pavoni, B., 2001. Macrofauna impact on Ulva rigida $\mathrm{C}$. Ag. Production and relationship with environmental variables in the Lagoon of Venice. Mar. Environ. Res. 52 (1), 27-49.

Bressan, G., De Luca, F., 1987. Will we live on seaweeds in the future? (i.e. usefulness and uses of seaweeds). Villaggio del Fanciullo, Trieste (in Italian).

Cescon, P., 1992. Characterization and speciation of heavy metals and other persistent chemical pollutants for a more complete evaluation of their ecotoxicity. Sistema Lagunare Veneziano, Linea di ricerca 1.8 (in Italian).

Cincinelli, A., Stortini, A.M., Perugini, M., Checchini, L.L., 2001. Organic pollutants in sea-surface microlayer and aerosol in the coastal environment of Leghorn (Tirrenian Sea). Mar. Chem. 76, 77-98.

COM, 2001. Commission of the European Communities. 2000/0035 (COD), Brussels, 16.1, 2001 Ambended proposal for a decision of the European parlament and of the Council establishing the list of priority substances in the field of water policy.

Cubadda, F., Stacchini, P., Baldini, M., 1998 Rapporti ISTISAN, 98/11, ISTISAN (in Italian). Organic and inorganic micropollutants in edible marine species of Adriatic Sea: presence levels and estimate of potential human uptake.
Erickson, M.D., 1997. Analytical Chemistry of PCBs. Lewis Publishers, New York.

Fernández M.A., Alonso C., Gonzáles Ma. J. and Hernández, L.M., 1999. Occurrence of organochlorine insecticides, PCBs and PCB congeners in waters and sediments of the Ebro river (Spain). Chemosphere 38, 33-43.

Gatto, P., Carbognin, L., 1981. The Lagoon of Venice: natural environmental trend and man-induced modification. Hydrol. Sci. Bull. 26 (4), 379-391.

Haritonidis, S., Malea, P., 1995. Seasonal and local variation of $\mathrm{Cr}$, Ni and Co concentrations in Ulva rigida C. Agardh and Enteromorpha linza Linnaeus from Thermaikos Gulf, Greece. Environ. Pollut. 89, 319-327.

Haritonidis, S., Malea, P., 1999. Bioaccumulation of metals by the green alga Ulva rigida from Thermaoikos Gulf, Greece. Environ. Pollut. 104, 365-372.

Hope, B., Scatolini, S., Titus, E., Cotter, J., 1997. Distribution patterns of polychlorinated biphenyl congeners in water, sediment and biota from Midway Atoll (North Pacific Ocean). Mar. Pollut. Bull. 34, 548-563.

Karez, C.S., Magalhaes, V.S., Pfeiffer, W.C., Amado Filho, G.M., 1994. Trace metal accumulation by algae in Sepetida Bay, Brazil. Environ. Pollut. 83, 351-356.

Keiji, I., Kanji, H., 1989. Seaweeds: chemical composition and potential food uses. Food Rev. Int. 5, 101-144.

Kennish, M.J., 1994. Marine pollution. second ed. Practical Handbook of Marine Science. CRC Press, Boca Raton, FL.

Levine, H.G., 1984. The use of seaweeds for monitoring coastal waters. In: Shubert, L.E (Ed.), Algae as Ecological Indicators. Academic Press, London, pp. 189-210.

Marchand, M., Abarnou, A., Marcaillou-Lebaut, C., 1990. Polychlorobiphenyl (PCBs) in marine environment, biogeochemistry and ecotoxicology. IFREMER, Rapports scientifiques et techniques de l'IFREMER. IFREMER, pp. 113-129 No. 18 (in French).

Malea, P., Haritonidis, S., 1999a. Metal content in Enteromorpha linza (Linnaeus) in Thermaikos Gulf (Greece). Hydrobiologia 394, 103-112.

Malea, P., Haritonidis, S., 1999b. Seasonal accumulation of metals by red alga Gracilaria verrucosa (Huds.) Papenf. from Thermaikos Gulf, Greece. J. Appl. Phycol. 11, 503-509.

Maroli, L., Pavoni, B., Sfriso, A., Raccanelli, S., 1993. Concentrations of polychlorinated biphenyls and pesticides in different species of macroalgae from the Venice Lagoon. Mar. Pollut. Bull. 26, 553-558.

Moret, I.R., Piazza, A., Gambaro, M., Benedetti, P., Cescon, 1999. Polychlorobiphenyls (PCBs) in the sediments and surface water of the Venice Lagoon. Organohalogen Compd. 40, 223-226.

Morand, P., Briand, X., 1996. Excessive growth of macroalgae: a symptom of environmental disturbance. Bot. Mar. 39, 491-516. 
Moy, F.E., Walday, M., 1996. Accumulation and depuration of organic micro-pollutants in marine hard bottom organisms. Mar. Pollut. Bull. 33, 56-63.

Neff, J.M., 1979. Polycyclic Aromatic Hydrocarbons in the Aquatic Environment (Sources, Fates and Biological Effects). Applied Science LTD Publishers, London.

Orlandini, M., Favretto, L., 1987. Utilisation of macroalgae in Italy for pollution abatement and as source of energy and chemicals Proceeding of the third COST 48-subgroup, Crema-L'Houmeau, CNRS-IFREMER, France. 25-28.

Pavoni, B., Calvo, C., Sfriso, A., Orio, A.A., 1990. Time trend of PCB concentrations in surface sediments from a hyper-trophic, macroalgae populated area of the Lagoon of Venice. Sci. Total Environ 91, 13-21.

Pavoni, B., Marcomini, A., Sfriso, A., Donazzolo, R., Orio, A.A., 1992. Changes in an estuarine ecosystem. The Lagoon of Venice as a case study. In: Dunnette, A.D., O'Brien, R.J. (Eds.), The Science of Global Change. American Chemical Society, Washington, DC, USA, pp. 287305 .

Penso, G., 1987. Medical Plants in Medical Therapy. OEMF S.p.A, Milan (in Italian).

Picer, M., 2000. DDT and PCBs in the Adriatic Sea. Croat. Chem. Acta 73 (1), 123-186.

Prosi, F., 1983. Heavy metals in aquatic organisms. In: Foerstner, U., Wittmann, G.T.W. (Eds.), Metal Pollution in the Aquatic Environment. Springer, Berlin, pp. 270-318.

Raccanelli, S., Pavoni, B., Marcomini, A., Orio, A.A., 1989. Polychlorinated biphenyl pollution caused by re-suspension of surface sediments in the Lagoon of Venice. Sci. Total Environ. 79, 111-123.

Raccanelli, S., Pavoni, B., Maroli, L., Sfriso, A., 1994. One step clean-up and separation of chlorinated, aliphatic and polycyclic aromatic hydrocarbons in environmental samples, prior to gas chromatographic quantification. Toxicol. Environ. Chem. 45, 121-137.

Schulz-Bull, D.E., Petrick, G., Bruhn, R., Duinker, J.C., 1998. Chlorobiphenyls (PCB) and PAHs in water masses of the northern North Atlantic. Mar. Chem. 61, 101-114.
Schramm, W., Nienhuis, P.H., 1996. Marine Benthic Vegetation. Recent Changes and the Effects of Eutrophication. Ecological Studies. Springer, Berlin, pp. 470 p. 470.

Sfriso, A., 2000. Eutrophication and pollution of waters and sediments in the central part of the Venice Lagoon. Nuovi Interventi per la Salvaguardia di Venezia, Consorzio Venezia Nuova, Magistrato alle Acque di Venezia, 3 vol. Ministero dei Lavori Pubblici Venice (in Italian).

Sfriso, A., 1987. Flora and vertical distribution of macroalgae in the Lagoon of Venice: a comparison with previous studies. G. Bot. Ital. 121, 69-85.

Sfriso, A., Pavoni, B., Marcomini, A., Orio, A.A., 1992. Macroalgae, nutrient cycles, and pollutants in the Lagoon of Venice. Estuaries 15, 517528.

Sfriso, A., Ghetti, P.F., 1998. Seasonal variation in biomass, morphometric parameters and production of seagrasses in the Lagoon of Venice. Aquat. Bot. 61, 207-223.

Sfriso, A., Pavoni, B., 1994. Macroalgae and phytoplankton competition in the central Venice Lagoon. Environ. Technol. 15, 1-14.

Strandberg, B., Van Bavel, B., Bergqvist, P.A., Broman, D., Ishaq, R., Näf, C., Pettersen, H., Rappe, C., 1998. Occurrence, sedimentation, and spatial variations of organochlorine contaminants in settling particulate matter and sediments in the northern part of the Baltic Sea. Environ. Sci. Technol. 32, 1754-1759.

Van Loon, G.W., Duffy, S.J., 2000. Environmental chemistry of colloids and surfaces. Environmental Chemistry, a Global Perspective. Oxford University Press, New York.

Wetzel, D., 2000. Novel techniques and temporal trends in assessing the distribution of petroleum hydrocarbon contamination and accumulation in the canals of Venice, Italy: 1985-1998. Department of Marine Science, University of South Florida (Graduate School), St. Petersburg, USA Ph.D. Dissertation.

Yunker, M.B., Macdonald, R.W., Vingarzan, R., Mitchell, R.H., Goyette, D., Sylvestre, S., 2001. PAHs in the Fraser River basin: a critical appraisal of $\mathrm{PAH}$ ratio as indicator of PAH source and composition. Org. Geochem. $33,489-515$. 